\title{
Environmental drivers explain regional variation of changes in fish and invertebrate functional groups across the Mediterranean Sea from 1994 to 2012
}

\author{
Anik Brind'Amour ${ }^{1, *}$, Marie-Joëlle Rochet ${ }^{1}$, Francesc Ordines ${ }^{2}$, Geoffrey R. Hosack ${ }^{3}$, \\ Olivier Berthelé ${ }^{1}$, Bastien Mérigot ${ }^{4}$, Pierluigi Carbonara ${ }^{5}$, Maria Cristina Follesa ${ }^{6}$, \\ Angélique Jadaud ${ }^{7}$, Evgenia Lefkaditou ${ }^{8}$, Porzia Maiorano ${ }^{9}$, \\ Panagiota Peristeraki ${ }^{8}{ }^{10}$, Alessandro Mannini ${ }^{11}$, Manuella Rabiller ${ }^{1}$, \\ Maria Teresa Spedicato ${ }^{5}$, George Tserpes ${ }^{8}$, Verena M. Trenkel ${ }^{1}$
}

${ }^{1}$ IFREMER, Unité Ecologie et Modèles pour l'Halieutique, rue de l'Ile d'Yeu, BP 21105, 44311 Nantes cedex 3, France ${ }^{2}$ Instituto Español de Oceanografía, Centre Oceanogràfic de Balears, Moll de Ponent s/n, 07015 Palma de Mallorca, Spain

${ }^{3}$ CSIRO Marine Laboratories, GPO Box 1538, Hobart, Tasmania 7001, Australia

${ }^{4}$ Université de Montpellier, UMR MARBEC, Station Ifremer, Avenue Jean Monnet, BP 171, 34203 Sète, France

${ }^{5}$ COISPA Tecnologia \& Ricerca, Stazione Sperimentale per lo Studio delle Risorse del Mare, Viadei Trulli, 18/20, 70126 Bari - Torre a Mare, Italy

${ }^{6}$ Department of Life Science and Environment, University de Cagliari, Via T. Fiorelli, 1, 09126 Cagliari, Italy ${ }^{7}$ IFREMER, Laboratoire Halieutique Mediterranée, UMR MARBEC, Avenue Jean Monnet, BP 171, 34203 Sète, France

${ }^{8}$ Hellenic Centre for Marine Research, Institute of Marine Biological Resources and Inland Waters, PO BOX 712, 19013 Anavissos, Greece

${ }^{9}$ Department of Biology, University of Bari Aldo Moro, Via Orabona, 4 - 70125 Bari, Italy

${ }^{10}$ Biology Department, University of Crete, Heraklion, 71003, Crete, Greece

${ }^{11}$ University of Genova, Dip. Te. Ris., Viale Benedetto XV, 3 - 16132 Genoa, Italy

\begin{abstract}
Functional groups are sets of species that play a similar role in a food web. We defined functional groups of fish species based on their morphological characteristics, while using expert knowledge for invertebrates. We measured 9 morphological traits of 72 fish species, and carried out multivariate analyses to assign fish species to functional groups. The analysis identified 9 trait-based fish functional groups to which were added 3 expert-based invertebrate functional groups. The habitat (position in the water column) and potential diet of each group were identified from the literature. Using the MEDITS bottom trawl survey data collected at 10 to $800 \mathrm{~m}$ depth, we calculated relative change in the 12 fish and invertebrate functional group biomasses for 12 Mediterranean areas over the period 1994 to 2012. Multiple regression trees identified 4 regions with similar changes: (1) the Adriatic and the Ionian Sea; (2) the Tyrrhenian Sea and the Strait of Sicily; (3) the Balearic Islands and other enclosed areas such as the Gulf of Lions and Aegean Sea; and (4) the Ligurian Sea and Sardinia. The biomass of all functional groups increased or remained stable in the first 2 regions, while around half the functional group biomasses decreased in the other 2 regions. These regional differences in functional group biomass changes were mainly associated with regional variations in the time trends of bottom water temperature $(37 \%)$, bottom water dissolved oxygen $(23 \%)$ and mean catch levels $(9 \%)$. This study contributes to the EU Marine Strategy Framework Directive by proposing food web indicators based on morphologically and habitat defined functional groups.
\end{abstract}

KEY WORDS: Morphological traits · Community models - Functional network - Functional groups · Mediterranean Sea $\cdot$ Temporal trends $\cdot$ Fish $\cdot$ Shellfish 


\section{INTRODUCTION}

Evaluating the effects of human activities on the structure and ecological interactions in marine food webs is a major challenge for ecologists (Gårdmark et al. 2015, Möllmann et al. 2015). The challenge arises on the one hand from the diversity and complexity of food web interactions, and on the other hand from the range of human pressures and their interactions with variations in environmental conditions. One way of handling this complexity is to develop simplified functional networks based on groups of species, referred to as functional groups (Petchey \& Gaston 2006, Thompson et al. 2012). Here, functional groups are defined as sets of species that occupy the same habitat, play a similar role in the food web and whose dynamics can be considered consistent. Functional groups can respond more quickly and clearly than individual populations to anthropogenic and natural pressures (Rochet et al. 2010) and have proven useful for the analysis of community dynamics (McClanahan et al. 2008, Rochet et al. 2013).

Functional groups are the basic components of mass-balanced food web models, such as Ecosim with Ecopath (EwE; Christensen \& Pauly 1992) or linear inverse models (Vézina \& Platt 1988). Nevertheless, there appear to be no established rules about how to select the number of functional groups to be included in a food web model, and few studies have looked at the sensitivity of model results to this decision (Abarca-Arenas \& Ulanowicz 2002, but see Fulton et al. 2003). Interestingly, almost all modellers acknowledge the critical role of the number of groups for model results, particularly when food web indices are to be computed (Fulton et al. 2003).

For most ecosystem models, functional groups are defined in an ad hoc manner based on expert knowledge, literature reviews, and/or statistical analyses of diet data (e.g. Cartes et al. 2002, Stergiou \& Karpouzi 2002, Banaru et al. 2013), where the diet data may come from other regions. However, such approaches often assume low temporal and spatial variability in species' feeding preferences. These assumptions have been largely contradicted, notably by isotopic (Jennings et al. 1997) and stomach content studies (Pinnegar et al. 2003).

In contrast, significant relationships have been found between species' ecomorphological traits and spatial distributions, which can be explained by environmental conditions (Lamouroux et al. 2002, Brind'Amour et al. 2011), thereby relaxing the need for assuming spatially and temporally stable diets. Ecomorphological approaches have proved useful for investigating the relationship between morphology and certain ecological functions such as trophic function (Piet 1998, Sibbing \& Nagelkerke 2001, Albouy et al. 2011). Furthermore, recent functional group definitions have used ecomorphological approaches based on trophic-related traits such as size (Layman et al. 2005, Colloca et al. 2010, Gravel et al. 2013, Reecht et al. 2013), oral gap (Dumay et al. 2004, Albouy et al. 2011, Reecht et al. 2013) and gut length (Karachle \& Stergiou 2010a,b, Reecht et al. 2013). The theoretical basis for the use of morphological traits to assess functional groups is rooted in the habitat template theory (Southwood 1977). According to this theory, habitat characteristics act as filters for the selection of (morphological) traits suited to particular environmental conditions, including feeding. For a selection of relevant sets of morphological traits associated with the function of interest, the traits-based approach is an empirical and objective method of assembling species. Grouping species according to traits is also a way to increase the transferability of community models and/or allow the comparison of such models among ecosystems (Brind'Amour et al. 2011). Thus, ecosystems may differ in their species composition, but species are likely to form similar functional groups in different ecosystems (Guidetti et al. 2014).

The Mediterranean Sea is an intercontinental sea extending west-east from the Strait of Gibraltar between Spain and Morocco to the shores of the Gulf of Iskenderun on the southwestern coast of Turkey. It is characterized by several enclosed coastal areas (e.g. Gulf of Lion, Adriatic Sea) and narrow continental shelves (around $20 \%$ of its total surface; Coll et al. 2010). Mean surface temperature and salinity increase along a longitudinal gradient from west to east, and along a latitudinal gradient from north to south (MyOcean 2014). These physical and chemical gradients run opposite to primary production, which is higher in the northwestern areas and lower in the southeastern parts of the Mediterranean Sea (Danovaro et al. 1999). Changing environmental conditions have modified community composition across the Mediterranean Sea and favoured the introduction of non-indigenous species (see overview in Philippart et al. 2011). The Mediterranean Sea offers a diversity of environmental conditions to a diversity of marine organisms (Durrieu de Madron et al. 2011), and so is well-suited to a trait-based ecomorphological analysis.

European fisheries in the Mediterranean Sea are governed by a specific management framework (EC 2006). This framework combines effort controls with restrictions on fleets (fishing licenses, engine power limitations, cod-end mesh size, maximum length of 
nets, etc.), time-at-sea, minimum landing size, and various spatial management measures (temporal bans, restricted areas). For example, the use of towed gears is prohibited within 3 nautical miles of the coast or within the $50 \mathrm{~m}$ isobaths where that depth is reached at a shorter distance from the coast. In contrast to European Atlantic fisheries, Mediterranean fisheries are geographically limited, with most shelf areas being exploited only by vessels from the bordering country.

The aim of this study was to describe community structures across the northern continental shelves (10 to $800 \mathrm{~m}$ depth) of the Mediterranean Sea using the trait-based functional group approach, and to examine spatial and temporal patterns in functional groups over the last 2 decades. Given the strong geographic environmental gradients and the spatial management strategies, we hypothesized that geographical differences in functional group biomass changes arose as a result of these drivers.

\section{MATERIALS AND METHODS}

\section{MEDITS scientific surveys}

Biomass data were collected during annual bottom trawl surveys (MEDITS; Mediterranean International
Trawl Survey) conducted between May and July from 1994 to 2012 in 12 GSAs (Geographical SubAreas; www.gfcm.org) in the northern part of the Mediterranean Sea (Fig. 1). The data for certain GSAs have missing years. Hauls were performed over the continental shelf (10 to $200 \mathrm{~m}$ depth) and on the upper part of the continental slope (200 to $800 \mathrm{~m}$ ) within the framework of the MEDITS scientific project (Bertrand et al. 2002). All fish, cephalopods and other invertebrate species were weighed and counted. Identification was done to the lowest taxonomic level possible. Only taxa identified at the species level were assigned to one of the functional groups (see below) and kept for further analyses. The proportion of species included in the statistical analyses represented over $80 \%$ on average of the total biomass caught annually.

The retained species included pelagic species for which we assumed that the data collected from bottom trawl surveys could be used to assess spatiotemporal trends at the group level. We verified this assumption by comparing time trends of acoustic derived abundance and biomass estimates of several small pelagic species in the Gulf of Lions (C. Saraux unpubl. data) with the bottom trawl derived estimates used in this study (see Figs. S1 \& S2 in the Supplement at www.int-res.com/articles/suppl/m562 p019_supp.pdf). Significant rank correlations were

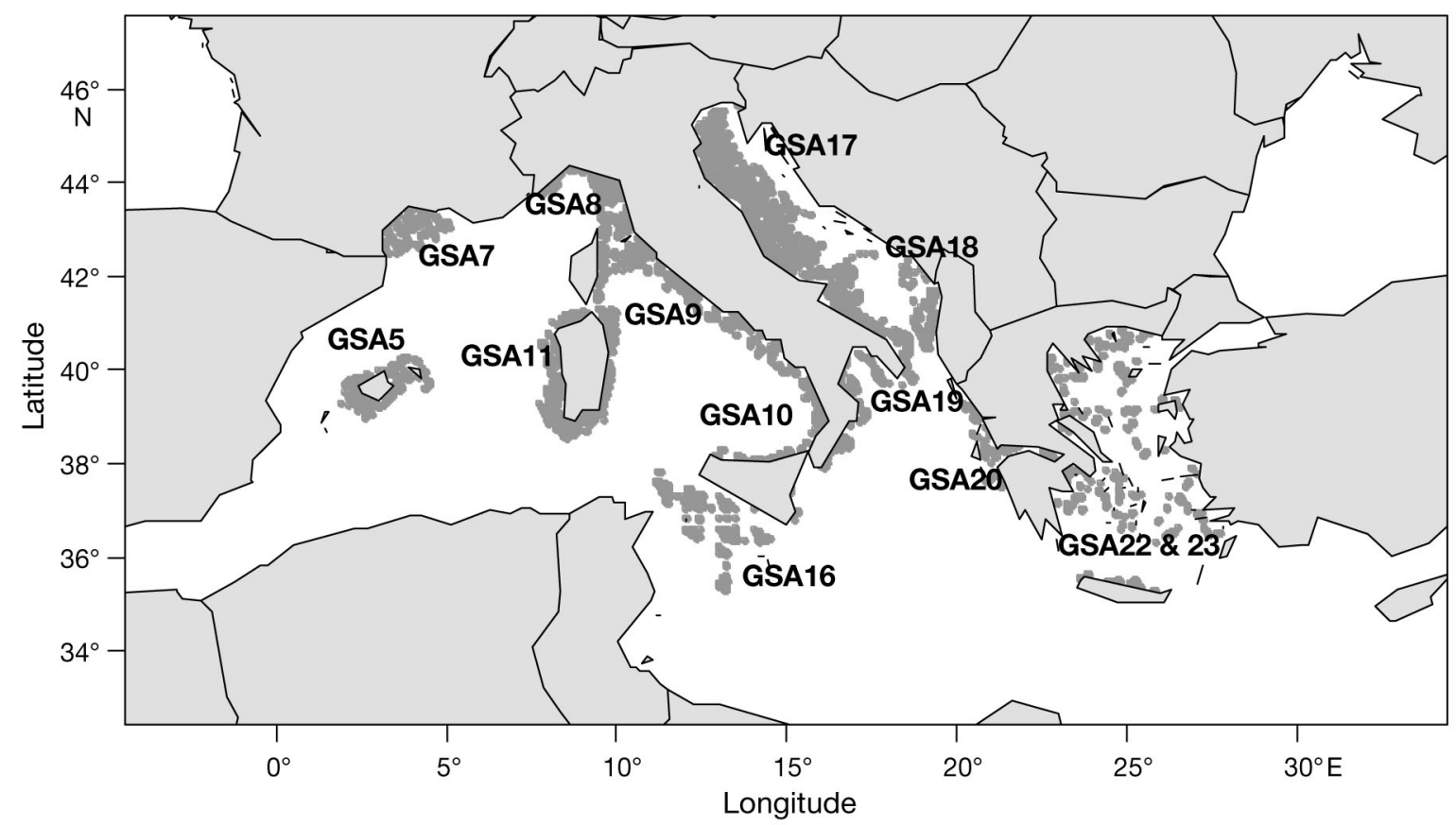

Fig. 1. Sampling stations in the 12 Geographical Sub-Area (GSAs) during the period 1994 to 2012. GSA5: Balearic Islands; GSA7: Gulf of Lions; GSA8: Corsica; GSA9: North and Central Tyrrhenian; GSA10: Southern Tyrrhenian; GSA11: Sardinia; GSA16: Strait of Sicily; GSA17: Northern Adriatic Sea; GSA18: Southern Adriatic Sea; GSA19: North-Western Ionian Sea; GSA20: Eastern Ionian Sea; GSA22: Aegean Sea and Crete (incl. GSA23) 
found for both biomass and abundance at the functional group level and for nearly $40 \%$ of species at the population level, which confirms the suitability of bottom trawl survey data to assess the spatial and temporal trends of pelagic species groups. Similar results were also observed by Fiorentino et al. (2013) in the Strait of Sicily for Sardina pilchardus and Engraulis encrasicolus. They compared MEDITS biomass and abundance data with acoustics data from the Mediterranean International Acoustic Survey (MEDIAS) over $16 \mathrm{yr}$ of surveys, and concluded that MEDITS bottom trawl surveys represented a complementary source of information on the stocks of the 2 studied species.

\section{Species morphological traits}

Nine morphological traits related to habitat and diet were measured either in the field or from images of fish species using ImageJ software (version 1.47; http://imagej.nih.gov/ij/) (see Granger et al. 2015 for details and Brind'Amour et al. 2016 for the data) (Table 1). Organisms and pictures were collected in 7 GSAs between 2011 and 2013 on MEDITS bottom trawl surveys (GSA5, 7, 10, 11, 18, 19, 29), with an average of 30 species by area. Seven of the chosen traits consisted of ratios (to avoid size effects) calculated from continuous biological characteristics that had already proved useful for determining functional groups (Albouy et al. 2011, Reecht et al. 2013). The 2 remaining traits, body shape (Webb 1984) and pigmentation (Nikolsky 1963), were categorical. A total of 1486 individuals from 72 fish species were collected. For each species, continuous traits were computed as the mean of at least 3 individuals. We then used the species morphological traits matrix to build functional groups (FGs) (see 'Statistical analyses' below). Invertebrates were not included in these analyses.

Table 1. Morphological traits related to diet and habitat used to group fish species into functional groups

\begin{tabular}{|c|c|c|}
\hline Morphological trait & Calculation & Related function and ecological interpretation \\
\hline Body depth & Ratio. Standard length:body depth & $\begin{array}{l}\text { Diet. Related to the hydrodynamic ability of fish } \\
\text { species (Sibbing \& Nagelkerke 2001) }\end{array}$ \\
\hline Caudal length & Ratio. Caudal fin length:caudal fin depth & $\begin{array}{l}\text { Diet and prey capture. Associated with swimming } \\
\text { ability of fish. Small values indicate low swimming } \\
\text { ability }\end{array}$ \\
\hline Eye diameter & $\begin{array}{l}\text { Ratio. Diameter of the eye standardized by head } \\
\text { length }\end{array}$ & $\begin{array}{l}\text { Habitat and diet. Detection of prey and visual acuity } \\
\text { of predatory fish. Hunting fish have higher values }\end{array}$ \\
\hline Eye position & $\begin{array}{l}\text { Ratio. Distance between the bottom of the head } \\
\text { and the eye centre along the head depth axis:head } \\
\text { length }\end{array}$ & $\begin{array}{l}\text { Habitat. Assumed to be related to vertical position } \\
\text { in the water column. Low values (i.e. eyes laterally } \\
\text { positioned) indicates pelagic habitat, whereas high } \\
\text { values (i.e. eyes positioned dorsally) indicate a more } \\
\text { sedentary mode of life }\end{array}$ \\
\hline Pectoral fin position & $\begin{array}{l}\text { Ratio. Distance between the insertion of pectoral } \\
\text { fin and the bottom of the body:body depth at } \\
\text { the level of the pectoral fin insertion }\end{array}$ & $\begin{array}{l}\text { Diet. Related to manoeuvrability at slow speeds and } \\
\text { facility to maintaining position. Low values indicating } \\
\text { pectoral fin laterally positioned (i.e. highly manoeuvrable) }\end{array}$ \\
\hline Mouth depth & Ratio. Vertical oral gap:standard length & Diet. Size of the captured prey \\
\hline Oral gap position & $\begin{array}{l}\text { Ratio. Distance from the bottom of the head } \\
\text { to the mouth:head depth along the vertical axis } \\
\text { of the eye }\end{array}$ & $\begin{array}{l}\text { Habitat and diet. Feeding position in the water column } \\
\text { and size and types of potential prey. This ratio is closely } \\
\text { related to the categories of Motta et al. (1995) and } \\
\text { Dumay et al. (2004). Small ratios indicate mouth } \\
\text { ventrally positioned, whereas large ratios indicate a } \\
\text { terminal mouth position }\end{array}$ \\
\hline Pigmentation & Qualitative assignment from 1 to 4 & $\begin{array}{l}\text { Habitat and behaviour. Categories based on Nikolsky } \\
\text { (1963): (1) silvery or reflective side-solitary pelagic; }(2) \\
\text { countershading with dark lateral band-schooling pelagic; } \\
\text { (3) mottled pattern or vertical bars-vegetal or benthic } \\
\text { rocks; (4) countershading without either silveriness or } \\
\text { lateral band-benthic over a sand bottom }\end{array}$ \\
\hline Body shape & Qualitative assignment from 1 to 6 & $\begin{array}{l}\text { Habitat. Categories from Webb (1984) and the general } \\
\text { types of fish morphology: (1) fusiform; (2) compressed; } \\
\text { (3) round; (4) filiform; (5) depressed; (6) globe-like shape }\end{array}$ \\
\hline
\end{tabular}




\section{Environmental drivers}

Environmental and pressure variables were derived from MyOcean Products (MyOcean 2014) and landing statistics (FAO 2014, 2015). We selected environmental variables characteristic of environmental gradients (i.e. climate change and changes in productivity) and anthropogenic pressures (i.e. exploitation), for which effects on fish communities are documented in the literature. A subset of MyOcean environmental estimates were processed comprising monthly means for each of 3 environmental variables: temperature $\left({ }^{\circ} \mathrm{C}\right)$, total nitrate $\left(\mathrm{mmol} \mathrm{m}^{-3}\right)$, and dissolved oxygen $(\mathrm{mmol}$ $\mathrm{m}^{-3}$ ). Temperature was derived from the 3D Mediterranean Sea Physics Reanalysis model (19902012), whereas total nitrate and dissolved oxygen were taken from the 3D Mediterranean Sea Biogeochemistry Reanalysis model (1999-2010). Both models have a horizontal grid resolution of $1 / 16 \times$ $1 / 16^{\circ}$ with 72 unevenly spaced depth levels (Oddo et al. 2009). The model values corresponding to the deepest water (temperature and dissolved oxygen) or the surface (total nitrate) layer in each grid cell were selected at the locations of the survey hauls (see Fig. 1) and then averaged across locations within areas to obtain time series for each variable. It is worth stressing that the precision of environmental variables used here depended on the precision of the MyOcean models. Five summary statistics were prepared for each time series: average across annual means, minimum and maximum of annual means, standard deviation of annual means, and slope of a linear time trend model for mean values. These 5 statistics for the 3 environmental variables were used as explanatory variables for modelling relative FG biomass changes.

Landings statistics for the period 1994 to 2012 were extracted from the FAO database and served as a proxy for exploitation pressure. The FAO data were filtered by selecting species composing the FGs. The selected landings corresponded on average to $69 \%$ of total landings. The remaining $31 \%$ corresponded to higher level species groups (e.g. marine fish not elsewhere included [nei], marine molluscs nei). We then summed the species-specific landings by FAO division and divided them by the surface areas given in Caddy et al. (1995). The standardized catches (t $\mathrm{km}^{-2}$ ) by FAO division were then assigned to GSAs. This was done by assigning the same time series of landings to the GSAs pertaining to the same FAO division.

\section{Statistical analyses}

Fig. 2 provides an overview of the statistical analyses carried out for (1) defining FGs, (2) analysing spatial and temporal FG biomass changes, and (3) assessing the relationship between the environment and FG biomass changes. These steps are detailed below.

\section{Defining FGs}

Fish species were assigned to FGs by conducting a hierarchical cluster analysis (HCA) using Ward's agglomeration method (Ward 1963) on Gower's distance calculated for the species morphological traits matrix (Gower 1971). Gower's distance was chosen as we had both continuous and categorical variables with (sometimes) missing values. The number of groups to retain was determined using the Silhouette criteria (Rousseeuw 1987) and visually confirmed.

To test the significance of species FGs we carried out a 1-sided permutation test. Under the null hypothesis $\left(H_{0}\right)$, the average similarity (Sim) of morphological traits grouped together by the analysis described above does not differ significantly from the average similarity obtained under random groupings of species (Sim') for the same number of groups and the same number of species within each group. Under the alternative hypothesis $\left(H_{1}\right)$, the observed similarity is greater or equal to the one obtained by permutation, i.e. Sim $\geq$ Sim'. The test was carried out by (1) permuting the rows of the species $\times$ traits matrix (i.e. reallocating species among FGs), (2) estimating the similarity within each random FG, (3) computing the average of all within-FG similarities, (4) building the distribution of similarities under $H_{0}$ based on steps 1 to 3 for 9999 permutations, and (5) calculating the proportion of permuted values being equal to, or larger than, the observed similarity value; this proportion is the $\mathrm{p}$-value under $H_{0}$.

We compared the species composition of the traitsbased FGs with 4 qualitative trophic (invertebrate, invertebrate and fish, fish, and plankton feeders) and 6 habitat guilds (benthic, demersal, benthodemersal, pelagic, bentho-pelagic, and reef) from the literature (Harmelin-Vivien et al. 1989, Relini et al. 2002, Stergiou \& Karpouzi 2002, Le Bourg et al. 2015, Froese \& Pauly 2016) using the Adjusted Rand Index (ARI; Hubert \& Arabie 1985). The ARI is commonly used in data clustering as a measure of the similarity between 2 partitions. It represents a value between 0 


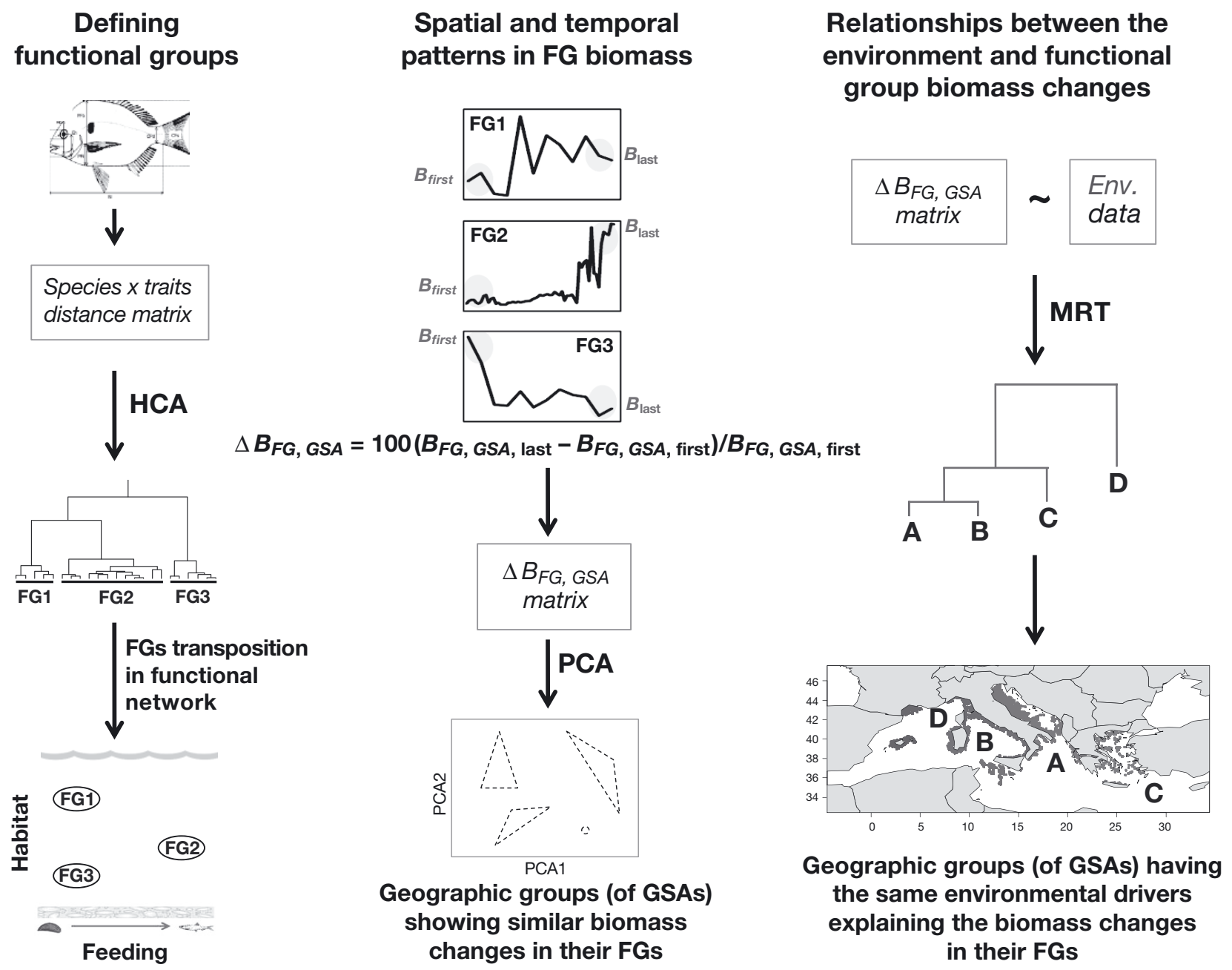

Fig. 2. Datasets and statistical analyses conducted to define fish functional groups (FGs), assess spatial and temporal patterns in fish and invertebrate functional group biomass changes, and test relationships between the environment and fish and invertebrate functional group biomass changes. MRT: multivariate regression tree; PCA: principal components analysis; HCA: hierarchical cluster analysis; $B$ : biomass

and 1 , with 0 indicating that the 2 partitions do not agree for any species and 1 indicating that the partitions are exactly the same.

After building FGs, we created a functional network by ordering FGs along 2 dimensions: diet (horizontal axis) and habitat (vertical axis). The groups were ordered, based on our results and on diet and habitat information gathered from the literature (e.g. Stergiou \& Karpouzi 2002, Kalogirou et al. 2012). To complement the functional network, we added 5 FGs corresponding to benthic cephalopods (3 species), pelagic cephalopods (3 species), benthic megafauna (4 species), plankton, and large fish predators. No morphological data were available for these supplementary groups, but biomass time series were available for the 2 cephalopod groups and the benthic megafauna.

\section{Identifying spatial and temporal patterns in FG biomass}

We summarised temporal trends in FG biomasses by computing the relative percentage difference in biomass between the mean biomass of the first $3 \mathrm{yr}$ $\left(B_{\mathrm{FG}, \text { first }}\right)$ and the mean for the last $3 \mathrm{yr}\left(B_{\mathrm{FG}, \text { last }}\right)$ for each functional group: $\Delta B_{\mathrm{FG}}=100\left(B_{\mathrm{FG}, \text { last }}-B_{\mathrm{FG}, \text { first }}\right) / B_{\mathrm{FG}, \text { first }}$. The bottom trawl data were used for all functional groups except plankton and large predators, which are not caught by the MEDITS gear. Biomass data were standardized by swept area without correction for differences in catchability. The calculations were carried out for all FGs represented in the functional network, except for large predators and plankton.

We searched for regional patterns in FG temporal changes by conducting a principal components analysis (PCA) on the matrix of biomass changes $\left(\Delta B_{\mathrm{FG}}\right)$, 
with areas (GSAs) organized by rows and FGs by columns.

\section{Assessing relationships between environment, landings and functional groups}

Relationships between relative FG biomass changes (i.e. $\Delta B_{\mathrm{FG}}$ ) in the 12 GSAs (response variables) and environmental drivers as well as landings (explanatory variables) were tested using a multivariate regression tree (MRT) (Breiman et al. 1984, De'ath \& Fabricius 2000, De'ath 2002). The MRT was conducted on the matrix of biomass changes (i.e. $\Delta B_{\mathrm{FG}}$ ). MRT is a recursive partitioning method that splits the dataset of response variables successively into 2 groups, so that the variance in response variables within groups is minimized. The splitting procedure is continued until an over large tree is grown. It is then pruned back using a cross-validation method to define the size of the final tree. MRT can be used in cases of non-linear relationships between response and explanatory variables and multimodal distributions of response variables. MRTs were developed using the 'mvpart' function (Therneau \& Atkinson 2011) in the R software (R Development Core Team 2015).

\section{RESULTS}

\section{Defining functional groups}

Mean body size of the 72 retained species ranged from $6 \mathrm{~cm}$ (Capros aper) to $72 \mathrm{~cm}$ (Lepidopus caudatus). Hierarchical cluster analysis of morphological traits separated the species into 2 major clusters, with overall 9 FGs, bentho-pelagic (FG1, FG5, FG6, FG7, FG9), and benthic groups (other FGs) (Figs. 3 \& 4, Table S1 in the Supplement at www.int-res.com/ articles/suppl/m562p019_supp.pdf). Bentho-pelagic groups were further divided into pelagic and demersal groups.

The first pelagic group (FG1) was mainly characterized by species with countershading bodies and species with silvery/reflective sides and large eye diameters, suggesting schooling fish foraging for moving prey in the water column or near the sea bottom (Table 2). This group included nekton feeders feeding mainly on zoopankton (e.g. Engraulis encrasicolus) (Table S1). The second pelagic group (FG5) was composed of laterally-compressed species feeding chiefly on large zoobenthos and fish (e.g. Pagellus erythrinus). Fish included in FG5 had large mouth depths, indicative of feeding on large demersal prey.

The 3 demersal groups were composed of species with elongated bodies compressed anteriorly, feeding nocturnally in mid-water mainly on fish and cephalopods (FG6; e.g. Conger conger); fusiform species with mottled pattern or vertical bars living over sandy or rocky substrates feeding mainly on benthic fauna, small cephalopods, and fish (FG7; e.g. Scyliorhinus canicula); and round-shaped species feeding mainly on small invertebrates and fish, with the eyes dorsally positioned indicating a sedentary mode of life (FG9; e.g. Trachinus draco).

The 4 benthic groups of species were divided in 2 subgroups, one containing dorso-ventrally flattened species (FG2 and FG8) and the other, globe-like shaped species (FG3 and FG4). The first 2 groups are often buried in soft sediments and feed mainly on

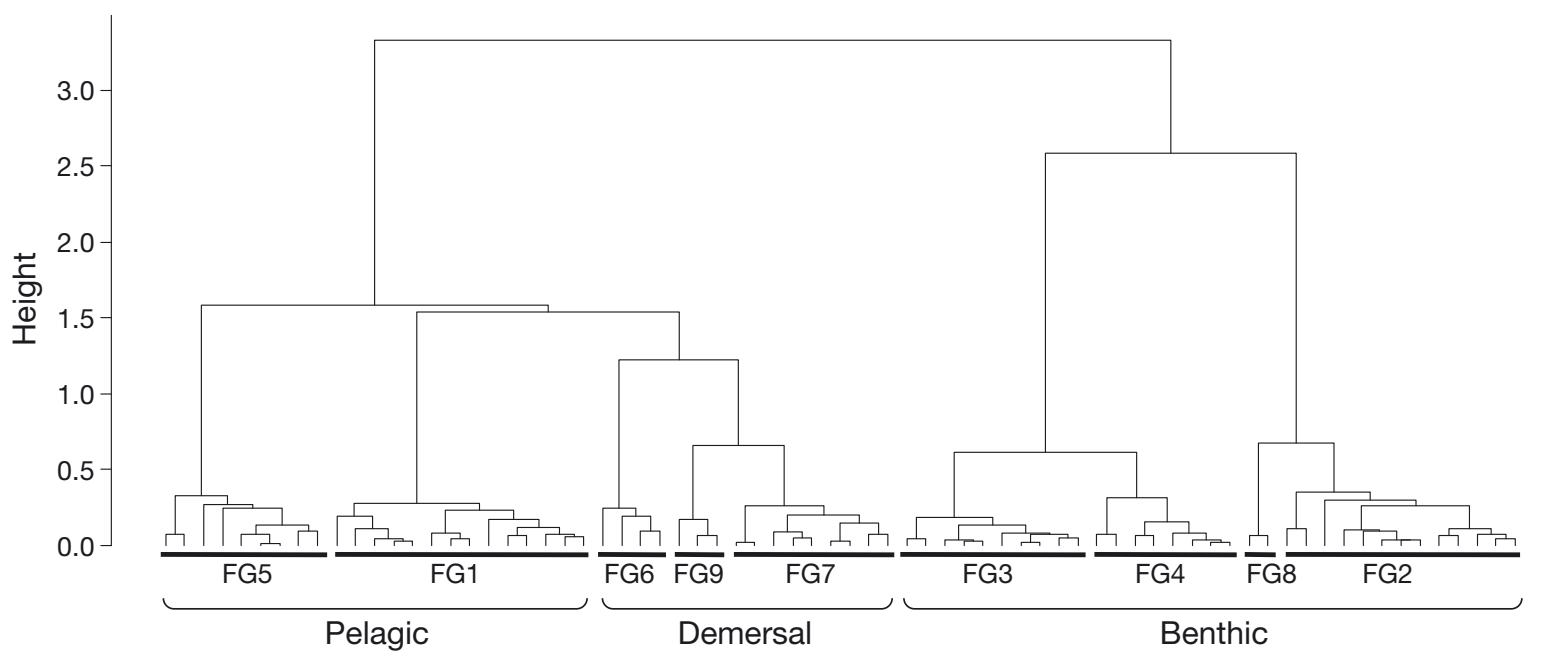

Fig. 3. Species groups as defined by the hierarchical cluster analysis on the average values of morphological traits by species (i.e. species traits matrix). The matrix included 72 species and 9 morphological traits (see Table 1). FG: functional group 


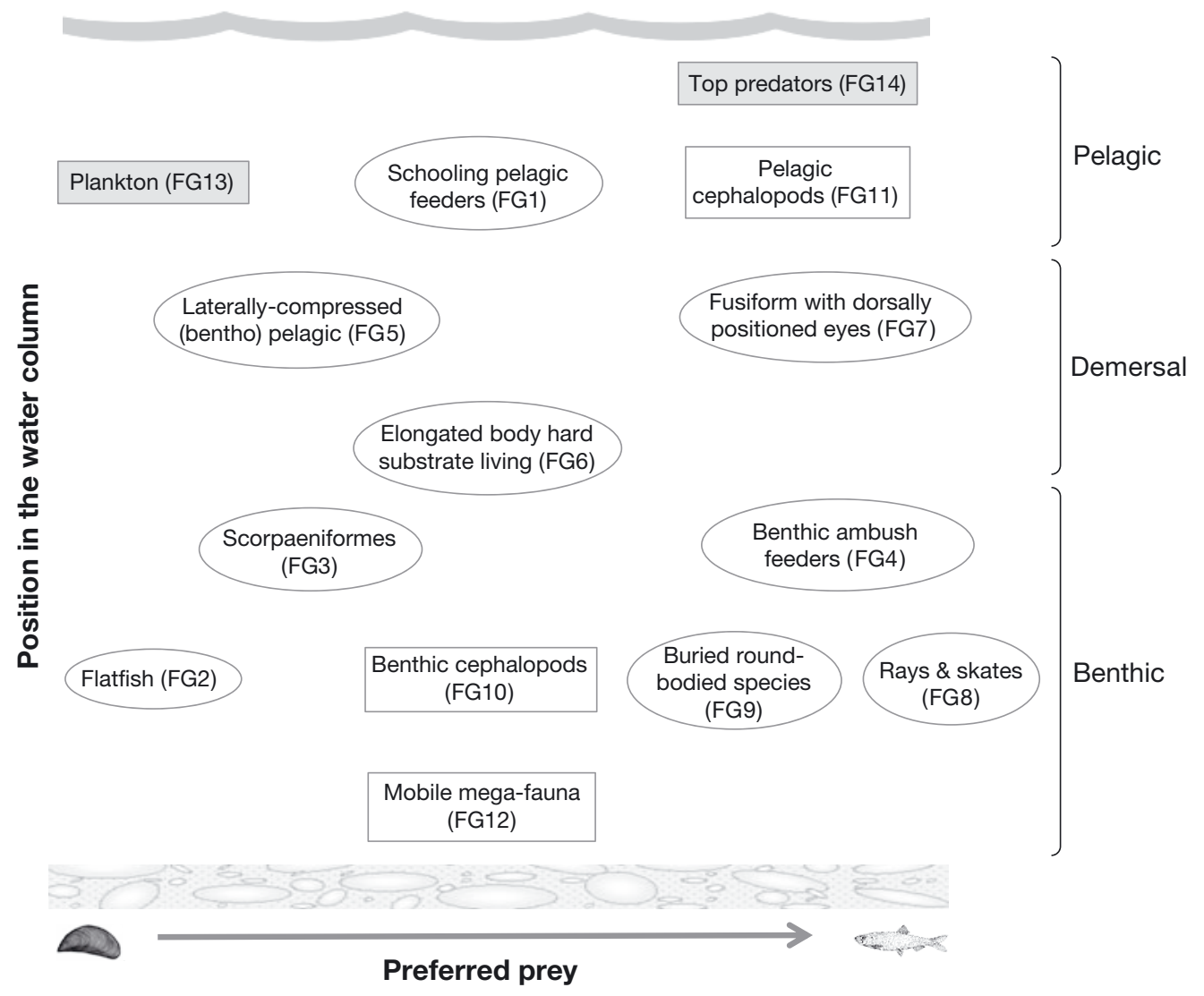

Fig. 4. Schematic food web drawn from the positioning of the 14 functional groups (FGs) included in the study. The $x$-axis shows the gradient of species' diets ranging from invertebrate to fish feeders, as assessed by the literature. Ellipsoid FGs were defined by traits-based analyses, whereas rectangular FGs were added based on expert judgement as no morphological traits were available (see Table 2 for a description of groups). The number in parentheses is the number of the FG. For grey groups, no biomass data were available but they were included to provide a synoptic view of the functional network

benthic macro-invertebrates or fish. The analysis separated rays (FG8) from flatfish (FG2). The 2 last groups were globe-like shaped species with either countershading, living over muddy/sandy substrates and feeding mainly on benthic invertebrates (FG3; e.g. Aspitrigla cuculus) or ambush feeders with wide mouths and mottled patterns or vertical bars indicative of good camouflage (FG4; e.g. Lophius piscatorius).

The significance of species FGs was tested using permutations. The results indicated that the average similarity in morphological traits between species of the same FG was $38 \%$ larger than the average similarity in morphological traits between species of randomly created FGs $(p<0.001)$.

When compared with literature-derived feeding and habitat guilds, the 9 FGs were poorly associated with the 6 feeding guilds (ARI $=0.05$ ) and moderately linked to the 4 habitat guilds (ARI $=0.22$ ) (see Table S1). Species groups created by combining feeding and habitat guilds were more dissimilar to FGs than habitat guilds alone (ARI $=0.07$ ).

\section{Spatial and temporal patterns in FG biomass}

The analysis of spatial and temporal patterns in group biomass changes was carried out for the 9 FGs described above plus 3 additional FGs (FG10, benthic cephalopods; FG11, pelagic cephalopods; and FG12, mobile benthic megafauna). No data were available for FG13 (plankton) and FG14 (large predators).

Comparison of the relative time trends during the period 1994 to 2012 for species within each FG revealed some opposing biomass trends. For example, in FG1, Trachurus trachurus mainly decreased whereas E. encrasicolus increased in several GSAs (see Table S2 in the Supplement). Such inconsistencies of species biomass changes were observed for several FGs, suggesting some degree of compensation. Furthermore, the species contributing most to the observed FG trends varied among GSAs, showing spatial differences in species dynamics within FGs.

Four broad temporal patterns emerged from the first 2 axes of the PCA of relative FG biomass 
Table 2. Ecological description of the functional groups (FGs) derived from morphological traits (Table 1) and expert knowledge. Habitat data derived from Stergiou \& Karpouzi (2002); main diet information from Harmelin-Vivien et al. (1989), Stergiou \& Karpouzi (2002), Relini et al. (2002), Le Bourg et al. (2015); and description information based on Harmelin-Vivien et al. (1989), Stergiou \& Karpouzi (2002), Relini et al. (2002), Le Bourg et al. (2015), and Froese \& Pauly (2016)

\begin{tabular}{|c|c|c|c|c|c|}
\hline FG & Group & Habitat & Main diet & Main species & Description \\
\hline 1 & $\begin{array}{l}\text { Schooling pelagic } \\
\text { feeders }\end{array}$ & $\begin{array}{l}\text { Pelagic or nocturnal } \\
\text { pelagic feeders }\end{array}$ & $\begin{array}{l}\text { Mainly nekton } \\
\text { (zooplankton or fish) }\end{array}$ & $\begin{array}{l}\text { Engraulis encrasicolus, } \\
\text { Spicara smaris }\end{array}$ & $\begin{array}{l}\text { Mainly species with countershading } \\
\text { body with dark lateral band (often } \\
\text { schooling) with large eye diameter. } \\
\text { Species feeding either on zooplank- } \\
\text { ton or nocturnally on cephalopods } \\
\text { and fish }\end{array}$ \\
\hline 2 & Flatfish & Benthic (buried) & $\begin{array}{l}\text { Mainly benthic endo- } \\
\text { and epifauna }\end{array}$ & $\begin{array}{l}\text { Citharus linguatula, } \\
\text { Lepidorhombus boscii }\end{array}$ & $\begin{array}{l}\text { Flatfish with countershading body } \\
\text { pigmentation, living over muddy or } \\
\text { sandy bottoms and feeding mainly } \\
\text { on macro-invertebrates }\end{array}$ \\
\hline 3 & Scorpaeniformes & Benthic & Epifauna and fish & $\begin{array}{l}\text { Eutrigla gurnardus, } \\
\text { Lepidotrigla cavillone }\end{array}$ & $\begin{array}{l}\text { Globe-like species with counter- } \\
\text { shading (without either silveriness } \\
\text { or lateral band) body pigmentation, } \\
\text { living over muddy or sandy bottoms } \\
\text { and feeding mainly on macro- } \\
\text { invertebrates and fish }\end{array}$ \\
\hline 4 & $\begin{array}{l}\text { Benthic ambush } \\
\text { species }\end{array}$ & Benthic & $\begin{array}{l}\text { Mainly fish and/or } \\
\text { zoobenthos }\end{array}$ & $\begin{array}{l}\text { Lophius budegassa, } \\
\text { Lophius piscatorius }\end{array}$ & $\begin{array}{l}\text { Globe-like species with wide mouth } \\
\text { and mottled pattern or vertical bars } \\
\text { indicative of good camouflage (rocky } \\
\text { ambush feeders). Species feeding } \\
\text { mainly on fish and benthic fauna }\end{array}$ \\
\hline 5 & $\begin{array}{l}\text { Laterally-compressed } \\
\text { bentho-pelagic }\end{array}$ & Bentho-pelagic & Zoobenthos & $\begin{array}{l}\text { Diplodus annularis, } \\
\text { Pagellus erythrinus }\end{array}$ & $\begin{array}{l}\text { Laterally-compressed species with } \\
\text { countershading pigmentation and } \\
\text { dark lateral band, feeding mainly } \\
\text { on worms, molluscs and small } \\
\text { crustaceans }\end{array}$ \\
\hline 6 & $\begin{array}{l}\text { Elongated body } \\
\text { hard substrate living }\end{array}$ & Demersal & $\begin{array}{l}\text { Mainly fish and } \\
\text { cephalopods }\end{array}$ & $\begin{array}{l}\text { Lepidopus caudatus, } \\
\text { Cepola macrophthalma }\end{array}$ & $\begin{array}{l}\text { Species with elongated body } \\
\text { compressed anteriorly, living over } \\
\text { sandy or rocky substrates, feeding } \\
\text { mainly on crustaceans, fish and } \\
\text { cephalopods }\end{array}$ \\
\hline 7 & $\begin{array}{l}\text { Fusiform with dorsally } \\
\text { positioned eyes }\end{array}$ & Demersal & Mainly fish & $\begin{array}{l}\text { Scyliorhinus canicula, } \\
\text { Galeus melastomus }\end{array}$ & $\begin{array}{l}\text { Fusiform species with mottled } \\
\text { pattern or vertical bars, living over } \\
\text { sandy substrates or benthic rocks, } \\
\text { feeding mainly on fish. Species with } \\
\text { eyes dorsally positioned (i.e. relat- } \\
\text { ively high values of eye position) }\end{array}$ \\
\hline 8 & Rays \& skates & Benthic (buried) & Mainly fish & $\begin{array}{l}\text { Raja clavata, } \\
\text { Raja asterias }\end{array}$ & $\begin{array}{l}\text { Dorso-ventrally flattened species } \\
\text { with mottled pattern or vertical bars } \\
\text { necessary for good camouflage } \\
\text { (ambush feeders). Species often } \\
\text { buried in sandy or gravely bottoms } \\
\text { and feeding mainly on fish }\end{array}$ \\
\hline 9 & $\begin{array}{l}\text { Round-bodied } \\
\text { demersal species }\end{array}$ & Demersal & $\begin{array}{l}\text { Fish and/or } \\
\text { zoobenthos }\end{array}$ & $\begin{array}{l}\text { Trachinus draco, } \\
\text { Uranoscopus scaber }\end{array}$ & $\begin{array}{l}\text { Round bodied and sedentary } \\
\text { species waiting for prey in sandy } \\
\text { or muddy bottoms }\end{array}$ \\
\hline $10^{\mathrm{a}}$ & Benthic cephalopods & Benthic & $\begin{array}{l}\text { Mainly large } \\
\text { zoobenthos }\end{array}$ & $\begin{array}{l}\text { Eledone cirrhosa, } \\
\text { Octopus vulgaris }\end{array}$ & $\begin{array}{l}\text { Benthic cephalopods feeding on } \\
\text { invertebrates }\end{array}$ \\
\hline $11^{\mathrm{a}}$ & $\begin{array}{l}\text { Pelagic and demersal } \\
\text { cephalopods }\end{array}$ & Pelagic & Mainly fish & $\begin{array}{l}\text { Illex coindetii, } \\
\text { Loligo vulgaris }\end{array}$ & $\begin{array}{l}\text { Cephalopods feeding mainly on fish } \\
\text { and crustaceans }\end{array}$ \\
\hline $12^{\mathrm{a}}$ & Mobile mega-fauna & Benthic & Carnivorous & $\begin{array}{l}\text { Nephrops norvegicus, } \\
\text { Parapenaeus longirostris }\end{array}$ & Benthos (mobile megafauna) \\
\hline $13^{\mathrm{b}}$ & Plankton & Pelagic & Invertebrates/algae & & Plankton \\
\hline $14^{\mathrm{b}}$ & Top predators & Pelagic & Fish & & Large piscivores \\
\hline
\end{tabular}




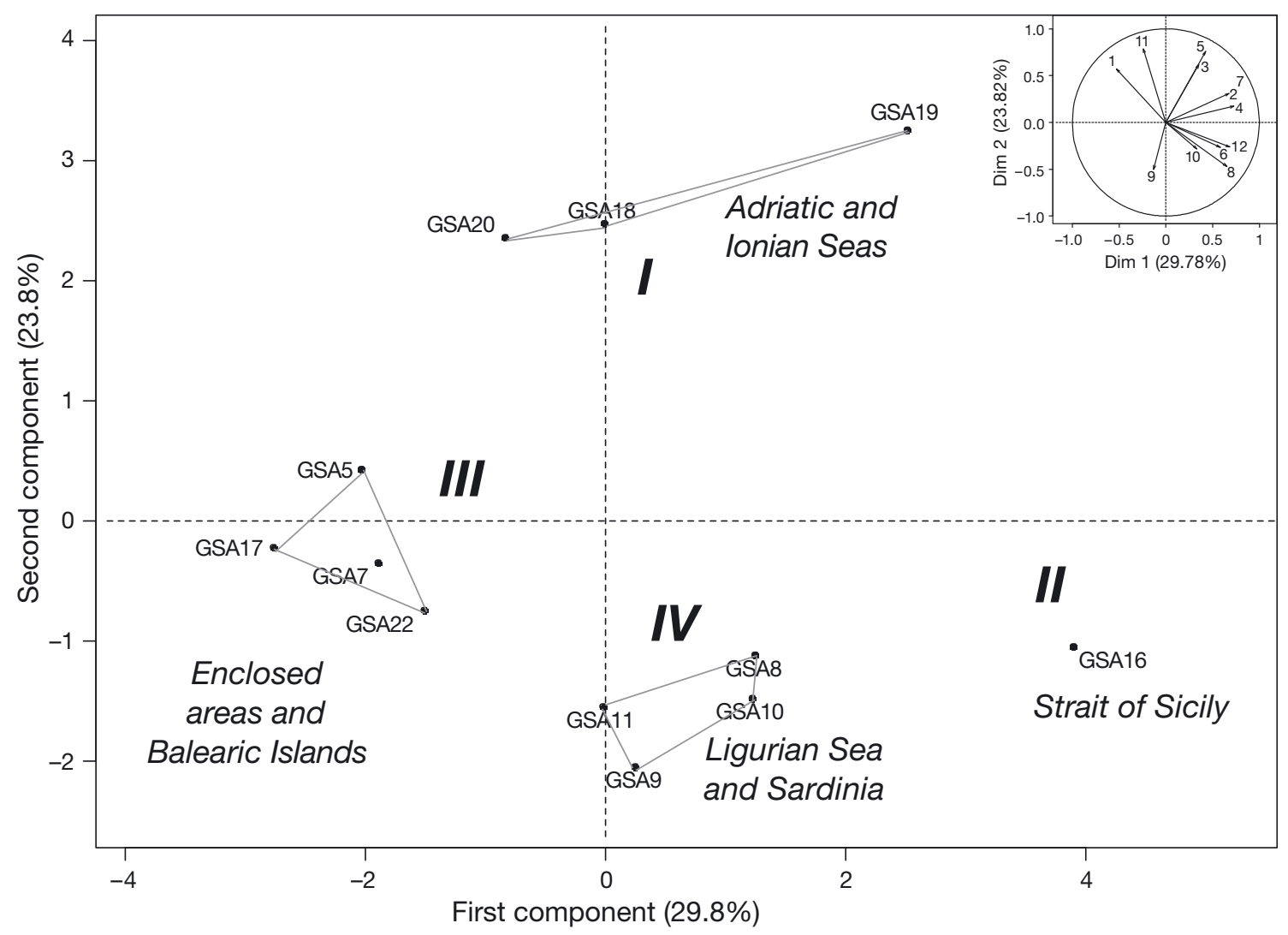

Fig. 5. Geographic clusters identified by principal components analysis (PCA) on the relative biomass changes in 12 Mediterranean geographic statistical areas (GSAs). The inset shows the contribution of the 12 functional groups (FGs) to the geographic pattern (see 'Results: Spatial and temporal patterns in FG biomass')

changes in the 12 GSAs (Fig. 5). The first pattern was shared by GSA18 (southern Adriatic Sea), and GSAs 19 and 20 (Western and Eastern Ionian Seas, respectively) ('I' in Fig. 5). In these areas the biomass of almost all FGs increased, notably in the pelagic FGs of the network. The group of pelagic cephalopods (FG11), the laterally-compressed bentho-pelagic species (FG5), and the schooling pelagic feeders (FG1) displayed on average, respectively 469,224 , and $125 \%$ more biomass at the end of the time series.

The second temporal pattern was exhibited by the Strait of Sicily (GSA16), where $83 \%$ of the FGs (10 of 12) showed biomass increases ('II' in Fig. 5). The largest biomass increase was found for rays (FG8) and demersal elongated species (FG6), with 666 and $502 \%$ biomass increase, respectively.

The third temporal pattern was shared by 3 GSAs encompassing enclosed bays (GSA7, Gulf of Lions; GSA17, Northern Adriatic Sea; and GSA22, Aegean Sea) and the Balearic Islands, GSA 5 ('III' in Fig. 5). It was characterized by a decrease in biomass in almost all FGs (8 of 12), especially in the benthic groups located at the bottom of their functional networks.
Mobile benthic megafauna (FG12), flatfish (FG2), and benthic cephalopods (FG10) decreased by 36, 41 , and $28 \%$, respectively, over the last 2 decades.

The fourth and final temporal pattern was shared by areas located in the western Mediterranean Sea (GSA8, Corsica; GSA11, Sardinia; GSA9, Ligurian Sea; and GSA10, Tyrrhenian Sea; 'IV' in Fig. 5). It was characterized by an increase in the lower compartments of their networks (benthic megafauna, FG12; flatfish, FG2; and rays, FG8) and small decreases in some pelagic FGs such as pelagic cephalopods (FG11), and schooling pelagic nekton feeders (FG1). The increase in benthic biomass ranged from 100 to $140 \%$, whereas pelagic biomasses decreased between 5 and $15 \%$.

Some FGs showed consistent biomass time trends across all studied areas. The group of elongated piscivorous species (FG8) decreased in all areas (75\% on average), except in the Strait of Sicily where it increased considerably $(222 \%)$. Species with laterallycompressed and fusiform bodies and eyes dorsally positioned (FG7) increased or remained stable in all areas. 

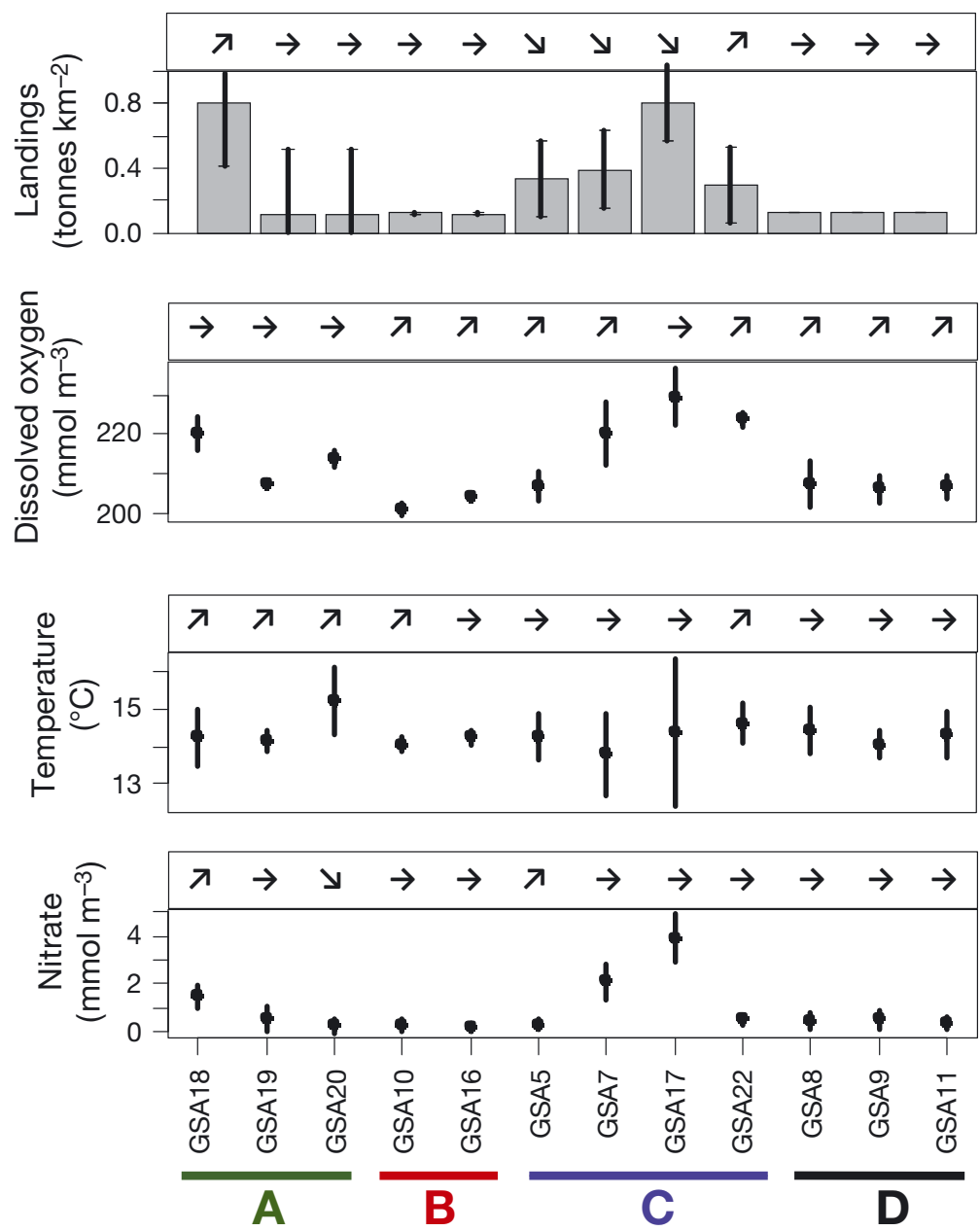

Fig. 6. Graphical summary of the spatial and temporal variability of 5 environmental variables considered in this study. The values correspond to averages across years of annual averages across sampling stations in Fig. 1. Bars indicate interannual standard deviations; arrows characterize linear trends in annual means estimated from linear regressions. The capital letters A to D correspond to the geographical groups of Geographical SubAreas (GSAs). FAO divisions and GSA correspondence for the landings: Gulf of Lions:GSA7; Adriatic Sea: GSA17, GSA18, GSA19, GSA20; Aegean Sea: GSA22, GSA23; Sardinia: GSA8, GSA9, GSA10, GSA11, and GSA16

Results from the MRT analysis conducted on the matrix of relative FG biomass changes underlined the significant explanatory contributions of interannual bottom water temperature variability $(36.8 \%$ of variance explained), dissolved oxygen temporal trends $(23.6 \%)$ and the average level of standardized FAO landings $(8.5 \%)$. These 3 variables explained over $69 \%$ of the total variability between areas, and separated the GSAs into 4 geographic groups (Fig. 7). The geographic groups matched almost perfectly those identified with PCA above (groups I to IV in Fig. 5) except for the South Tyrrhenian Sea (GSA10), which in the PCA was grouped together with western Mediterranean areas while in the MRT it clustered with the Strait of Sicily (GSA16).

The environment in the first geographic group ('A' in Fig. 7) including the Adriatic and the Ionian Seas, displayed no significant temporal trends in dissolved oxygen (average slope = 0.09), varying bottom water temperatures $\left(\mathrm{SD}=0.6^{\circ} \mathrm{C}\right)$, and medium landing levels $\left(0.35 \mathrm{t} \mathrm{km}^{-2}\right)$; concomitantly, all but 2 FGs increased. The second group, of GSAs ('B' in Fig. 7), spanning the Tyrrhenian Sea and the Strait of Sicily, was associated with small increases in dissolved oxygen (average slope $=0.35$ ), stable temperatures $\left(\mathrm{SD}=0.19^{\circ} \mathrm{C}\right)$, and low landings $\left(0.12 \mathrm{t} \mathrm{km}^{-2}\right)$. In this group, the biomass of all FGs increased, in particular those of demersal and benthic FGs. The third geographic group (' $\mathrm{C}$ ' in Fig. 7) was made up of enclosed areas

\section{Relationships between environment, landings and FGs}

Over the time period and spatial extent of the study, the 3 environmental variables representing near bottom water (temperature and dissolved oxygen) and surface water (total nitrate) environmental conditions displayed different patterns (Fig. 6). FAO landings and dissolved oxygen showed strong spatial variability but no geographic trend, while bottom water temperature exhibited no spatial variability. Surface total nitrate concentrations did not show any geographic trend but displayed high values in the Gulf of Lions and the Northern Adriatic Sea. (e.g. Gulf of Lions, Aegean Sea) and the Balearic Islands, in which the biomass of all FGs decreased, except that of pelagic groups. The near bottom water environment was characterized by a medium increase in dissolved oxygen (average slope $=0.46$ ), highly variable temperatures over the 2 decades $\left(\mathrm{SD}=1.06^{\circ} \mathrm{C}\right)$ and high landings $\left(0.46 \mathrm{t} \mathrm{km}^{-2}\right)$. The FG biomass changes (decrease or no changes in pelagic FGs and increase in benthic FGs) in the fourth geographic group (Ligurian Sea and Sardinia; 'D' in Fig. 7) were accompanied by large increases in dissolved oxygen (average time trend $=0.89$ ), variable temperatures $\left(\mathrm{SD}=0.53^{\circ} \mathrm{C}\right)$, and low landings $\left(0.12 \mathrm{t} \mathrm{km}^{-2}\right)$. 
a

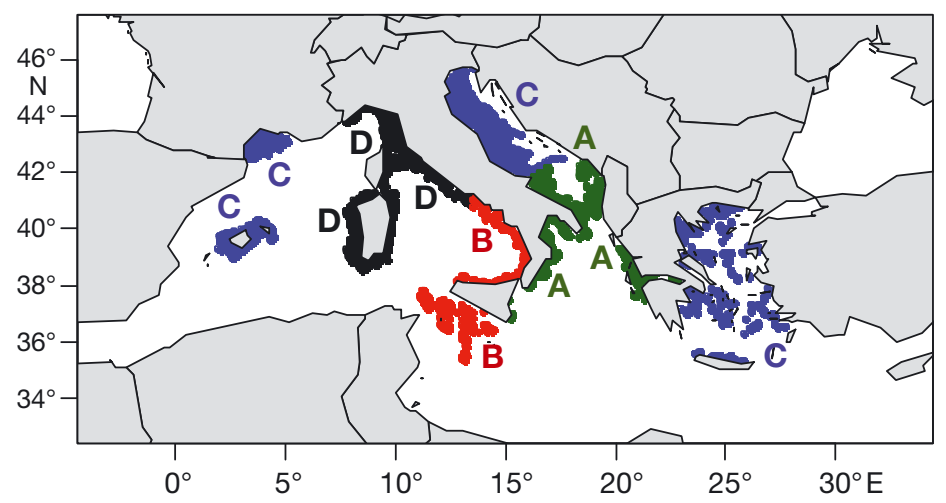

b
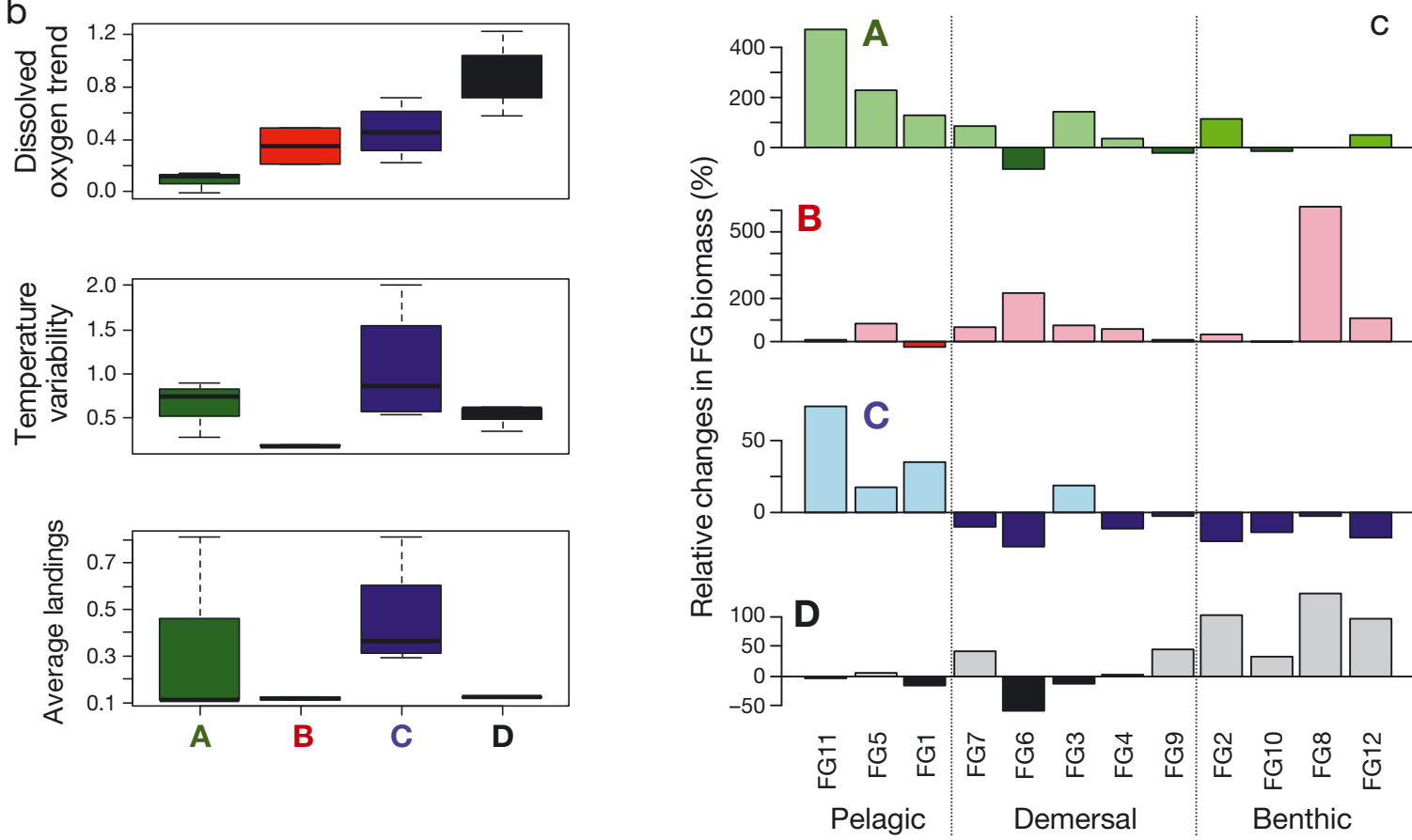

Fig. 7. (a) Membership of the 12 studied areas into 4 geographic groups (A to D) identified by multivariate regression tree analysis of functional group (FG) biomass changes. (b) Summary of the significant environmental variables, and (c) average relative temporal changes in FG biomass for each geographic group. In (b), the thick line is the median; the bottom and top of the boxes indicate the first and third quartiles, respectively; the ends of the whiskers are the lowest and highest data values

\section{DISCUSSION}

The Mediterranean Sea has experienced severe environmental and anthropogenic pressure changes during the last decades (increasing water temperature, fishing pressure, introduction of non-indigenous species; Lloret et al. 2001, Coll et al. 2010, Durrieu de Madron et al. 2011, Lotze et al. 2011), affecting species composition and thus diversity and food webs in various ways. Several studies have examined the temporal (Lotze et al. 2011) and spatial (Garibaldi \& Caddy 1998, Gaertner et al. 2007, Mouillot et al. 2011, Coll et al. 2012) distribution of a range of ecological indices, yet few have jointly analysed spatio- temporal trends of these indices (but see Rochet et al. 2010, Granger et al. 2015). According to our results, over the last 2 decades the biomasses of nearly half of the 12 studied FGs have increased on the continental shelf of the northern Mediterranean Sea, while a quarter decreased and another quarter remained stable. The relative changes in FG biomass in the bentho-pelagic network components of the Mediterranean Sea did not show any longitudinal or latitudinal trends, but were (1) mainly explained by interannual variability in bottom water temperature and dissolved oxygen, (2) weakly related to the level of landings, and (3) not at all related to surface total nitrate concentrations. 


\section{FGs of species}

Several studies have found that morphology is a poor indicator of diet (Motta et al. 1995, Albouy et al. 2011), though it is a better predictor of diet than body size alone (Reecht et al. 2013). We found little overlap between FGs and the trophic guilds identified in the literature, confirming the feeding plasticity of fish in comparison to the stringency of the habitat constraint. Indeed, the diet of species grouped in the same FG can differ or even include members of the same group (e.g. Blennius ocellaris and Scorpaena porcus in FG4; Harmelin-Vivien et al. 1989), leading to apparent trophic incongruities in our FGs. These incongruities might be explained by the fact that the selected morphological traits reflect the 'potential' niches of species, including both the habitat and trophic dimensions as defined by Hutchinson (1957). These incongruities can also be explained by intraguild predation, i.e. when predators are also competitors at certain age-classes (Polis \& Holt 1992). This is the case, for instance, in FG4 between $S$. porcus and B. ocellaris. Indeed, juveniles of $S$. porcus are competitors of $B$. ocellaris as they consume the same prey; however, as $S$. porcus grow, the adults may prey on $B$. ocellaris. It is thus not surprising to have, in some FGs, species sharing the same habitat but temporally differing in their diet. The diet of a species may also vary spatially, and opportunistic feeding is quite often observed (Trenkel et al. 2005). The habitat of a species can therefore be considered more stable than its observed diet. Further, Reecht et al. (2013) also found that a number of species show sizedependent (ontogenetic) shifts in morphological traits.

\section{Spatio-temporal changes in Mediterranean exploited ecosystems}

Studies investigating the spatial and/or temporal distribution of fish and benthic species have focused mainly on species diversity, such as beta and gamma diversity, functional diversity, and species richness (Gaertner et al. 2007, 2013, Mouillot et al. 2011, Granger et al. 2015), and to a lesser extent on community structure (Gaertner et al. 2005). Changes in FG biomass have not been assessed (to our knowledge) in the Mediterranean Sea and certainly not on such a large geographic scale, which makes comparison of our results with published studies difficult. In a paper reviewing the contributions of various food web models to the management of Mediterranean marine resources, Coll et al. (2012) recently acknowl- edged that spatio-temporal analyses of Mediterranean community time series should be considered a priority in the future. Such empirical analyses shed light on the potential mechanisms of changes in Mediterranean exploited communities and validate the data that can be further used in mechanistic models.

In a recent study, Granger et al. (2015) investigated the spatial and temporal variability of various functional, phylogenetic, and traditional species diversity indices across the Mediterranean Sea basin during the period 1994 to 2012 using the abundance of demersal fish species from the MEDITS data. While spatial variability was detected, they found high temporal stability in all indices. In contrast, in the present study (which used data from mostly the same surveys), we found significant temporal changes in functional group biomasses. These difference might be due to the fact that (1) the analysed data were different (abundance-based fish indices for Granger et al. 2015 versus biomasses of demersal, pelagic fish and invertebrate species in this study), and (2) time trends are difficult to identify using global measures of diversity such as species richness or Rao's functional diversity index (Rao 1964) or functional indices investigating specific facets of diversity (Villéger et al. 2008). Rao's index weighs the distance between species by their respective abundances, which means that temporal changes can be masked by compensation between functionally different species (Leibold et al. 1997, Hulot et al. 2014). In contrast, our FG approach focused solely on changes of functionally similar species. In addition, temporal changes in some of our FGs have been confirmed by local studies. For instance, using an ecosystem model for the Gulf of Lions and the Balearic Islands (geographic group C in this study), Corrales et al. (2015) identified the important role of schooling pelagic nekton feeders (here, FG1) and pelagic cephalopods (here, FG11) which we also found to be important for explaining differences in geographic groups (see Figs. 5 \& 7).

Some authors have interpreted the observed longitudinal gradient in fish community diversity in the Mediterranean Sea as resulting from productivity differences (e.g. Mouillot et al. 2011, Coll et al. 2012). In contrast, studies focusing on demersal species biomass (or abundance) from survey data found similar patterns to this study (Gaertner et al. 2007, 2013, Granger et al. 2015). Our modelling approach (MRT) divided the Mediterranean Sea into 4 broad geographic areas. This partition did not follow a strict longitudinal gradient but was explained by local 
environmental variables highly sensitive to oceanographic features such as bottom water temperature and dissolved oxygen concentration. Fishing levels also explained to a certain extent temporal changes in FGs across the Mediterranean areas.

Water temperature variability can modify community structure by favouring small species with higher metabolic rates and fast generation times - rates that can quickly adapt to environmental changes (Sommer et al. 1986). However, it is difficult to pinpoint any biological processes of temperature variability at the FG level as currently no studies have addressed such a question at this scale. Species with different tolerance ranges may compensate within a single FG (Peck et al. 2004). This is also the case for potential fishing effects that might be confounded with those of temperature changes (Rijnsdorp et al. 2009). Nevertheless, the GSA group (group C) with the highest number of decreasing FGs (i.e. 2/3 of FGs), and notably FGs including large piscivorous species (FG4, 7, 8, 9), were also those displaying the largest interannual temperature variability and the highest standardized landings.

The trend in dissolved oxygen concentration was also a significant variable explaining changes in functional composition of GSAs. Dissolved oxygen is expected to primarily affect benthic organisms (Diaz \& Rosenberg 1995) by imposing physiological constraints under hypoxic conditions. In this study, the group of GSAs with the largest temporal slope in dissolved oxygen (group D) was also the one with the largest increase in benthic FG biomass (FG2, 8, $10,12)$. However, the observed concentrations of dissolved oxygen were all above thresholds that would induce physiological stress on benthic organisms (Vaquer-Sunyer \& Duarte 2008).

\section{Practical implications}

The European Marine Strategy Framework Directive (MSFD; EC 2008) aims to achieve 'Good Environmental Status' of marine ecosystems by 2020. This EC directive reinforces the need for simple indicators, including for food web health (D4). One of the D4 indicators requires assessing 'abundance trends of functionally important selected groups/species' (indicator 4.3.1). Rombouts et al. (2013) noted the lack of operationality for this indicator. Our work is a direct contribution to the MSFD as it provides a methodology to define functional groups of species that can be compared across areas. The total biomass in each functional group could then be com- puted annually instead of being assessed between the beginning and the end of a time period, as was done here. To assess good environmental status, reference points could be derived from historical data or models.

Several modelling studies investigating threats to marine diversity and marine resources have been carried out in the Mediterranean Sea. These studies used ecosystem models such as EwE (Libralato et al. 2010, Banaru et al. 2013, Hattab et al. 2013, Moutopoulos et al. 2013) or qualitative loop analysis (Rochet et al. 2010). These modelling tools require a robust way of determining groups of species that will serve as building blocks for the model. For instance, the number of FGs defined in the different EwE models varied from 12 to 55, with an average of 31 groups (Coll \& Libralato 2012, Banaru et al. 2013, Hattab et al. 2013, Moutopoulos et al. 2013). Basing such functional groups upon the morphology of species might be an alternative or complementary way of determining the number of fish groups sharing the same habitat and/or prey. This is particularly relevant for studies aiming to investigate the impact of fishing on the ecosystem, as fisheries generally target several species simultaneously, and species caught together often have similar ecological requirements or occupy the same habitats (McClanahan et al. 2008).

In conclusion, our study revealed that Mediterranean fish communities have changed over the last 2 decades as a result of environmental drivers and fishing. Nearly half of the FGs increased in biomass while a quarter decreased and another quarter remained stable over the time period. The potential causes of these changes agree with those reported in the literature (Caddy 2000, Rochet et al. 2010, Garcia 2011, Coll et al. 2012). Finally, our study provides an objective way for grouping fish species into FGs that can serve as food web indicators.

Acknowledgements. The authors thank the crews of the different MEDITS surveys. We also acknowledge Axelle Denis, Carla Di Santo, Thomas Cavaillé and Andréa Theil who were involved in the species morphological measurements, and Claire Saraux for the PELMED dataset. Financial support was provided by the EU project PERSEUS (grant agreement number 287600). We are grateful to anonymous referees for their helpful reviews.

\section{LITERATURE CITED}

Abarca-Arenas LG, Ulanowicz RE (2002) The effects of taxonomic aggregation on network analysis. Ecol Modell 149:285-296

Albouy C, Guilhaumon F, Villéger S, Mouchet M and others (2011) Predicting trophic guild and diet overlap from 
functional traits: statistics, opportunities and limitations for marine ecology. Mar Ecol Prog Ser 436:17-28

Banaru D, Mellon-Duval C, Roos D, Bigot J and others (2013) Trophic structure in the Gulf of Lions marine ecosystem (north-western Mediterranean Sea) and fishing impacts. J Mar Syst 111-112:45-68

Bertrand J, De Sola L, Papaconstantinou C, Relini G, Souplet A (2002) The general specifications of the MEDITS surveys. Sci Mar 66(Suppl 2):9-17

Breiman L, Freidman JH, Olshen RA, Stone CJ (1984) Classification and regression trees. Wadsworth and Brooks/ Cole Publishing, Monterey, CA

Brind'Amour A, Boisclair D, Dray S, Legendre P (2011) Relationships between species feeding traits and environmental conditions in fish communities: a three-matrix approach. Ecol Appl 21:363-377

* Brind'Amour A, Mérigot B, Ordines F, Carbonara P and others (2016) Morphological traits measured for 89 fish species sampled in the Mediterranean Sea during MEDITS scientific surveys. SEANOE. http://dx.doi.org/ $10.17882 / 41825$

* Caddy JF (2000) Marine catchment basin effects versus impacts of fisheries on semi-enclosed seas. ICES J Mar Sci 57:628-640

Caddy JF, Refk R, Do-Chi T (1995) Productivity estimates for the Mediterranean: evidence of accelerating ecological change. Ocean Coast Manag 26:1-18

* Cartes JE, Abello P, Lloris D, Carboneli A, Torres P, Maynou F, de Sola LG (2002) Feeding guilds of western Mediterranean demersal fish and crustaceans: an analysis based on a spring survey. Sci Mar 66:209-220

* Christensen V, Pauly D (1992) ECOPATH II-a software for balancing steady-state ecosystem models and calculating network characteristics. Ecol Modell 61:169-185

Coll M, Libralato S (2012) Contributions of food web modelling to the ecosystem approach to marine resource management in the Mediterranean Sea. Fish Fish 13:60-88

Coll M, Piroddi C, Steenbeek J, Kaschner K and others (2010) The biodiversity of the Mediterranean Sea: estimates, patterns, and threats. PLOS ONE 5:e11842

Coll M, Piroddi C, Albouy C, Ben Rais Lasram F and others (2012) The Mediterranean Sea under siege: spatial overlap between marine biodiversity, cumulative threats and marine reserves. Glob Ecol Biogeogr 21:465-480

Colloca F, Carpentieri P, Balestri E, Ardizzone G (2010) Food resource partitioning in a Mediterranean demersal fish assemblage: the effect of body size and niche width. Mar Biol 157:565-574

Corrales X, Coll M, Tecchio S, Bellido JM, Fernández AM, Palomera I (2015) Ecosystem structure and fishing impacts in the northwestern Mediterranean Sea using a food web model within a comparative approach. J Mar Syst 148:183-199

Danovaro R, Dinet A, Duineveld G, Tselepides A (1999) Benthic response to particulate fluxes in different trophic environments: a comparison between the Gulf of LionsCatalan Sea (western-Mediterranean) and the Cretan Sea (eastern-Mediterranean). Prog Oceanogr 44:287-312

De'ath G (2002) Multivariate regression trees: a new technique for modeling species-environment relationships. Ecology 83:1105-1117

* De'ath G, Fabricius KE (2000) Classification and regression trees: a powerful yet simple technique for ecological data analysis. Ecology 81:3178-3192

Diaz RJ, Rosenberg R (1995) Marine benthic hypoxia: a review of its ecological effects and the behavioural responses of benthic macrofauna. Oceanogr Mar Biol Annu Rev 33:245-303

* Dumay O, Tari PS, Tomasini JA, Mouillot D (2004) Functional groups of lagoon fish species in Languedoc Roussillon, southern France. J Fish Biol 64:970-983

Durrieu de Madron X, Guieu C, Sempéré R, Conan P and others (2011) Marine ecosystems' responses to climatic and anthropogenic forcings in the Mediterranean. Prog Oceanogr 91:97-166

EC (2006) Council regulation (EC) No 1967/2006 of 21 December 2006 concerning management measures for the sustainable exploitation of fishery resources in the Mediterranean Sea, amending Regulation (EEC) No 2847/93 and repealing Regulation (EC) No 1626/94. Off J Eur Union L409:11-85

EC (2008) Directive 2008/56/EC of the European Parliament and of the Council of 17 June 2008 establishing a framework for community action in the field of marine environmental policy (Marine Strategy Framework Directive). Off J Eur Union L164:19-40

FAO (2014) FishStatJ - software for fishery statistical time series. Fisheries and aquaculture software, FAO, Rome

FAO (2015) FishStatJ-software for fishery statistical time series. Fisheries and aquaculture software, FAO, Rome

Fiorentino F, Patti B, Colloca F, Bonanno A and others (2013) A comparison between acoustic and bottom trawl estimates to reconstruct the biomass trends of sardine and anchovy in the Strait of Sicily (central Mediterranean). Fish Res 147:290-295

Froese R, Pauly D (eds) (2016) FishBase. www.fishbase.org (accessed Jan 2016)

Fulton E, Smith ADM, Johnson CR (2003) Effect of complexity on marine ecosystem models. Mar Ecol Prog Ser 253: $1-16$

KGaertner JC, Bertrand JA, De Sola LG, Durbec JP, Ferrandis E, Souplet A (2005) Large spatial scale variation of demersal fish assemblage structure on the continental shelf of the NW Mediterranean Sea. Mar Ecol Prog Ser 297: $245-257$

Gaertner JC, Bertrand JA, Relini G, Papaconstantinou C and others (2007) Spatial pattern in species richness of demersal fish assemblages on the continental shelf of the northern Mediterranean Sea: a multiscale analysis. Mar Ecol Prog Ser 341:191-203

*Gaertner JC, Maiorano P, Merigot B, Colloca F and others (2013) Large-scale diversity of slope fishes: pattern inconsistency between multiple diversity indices. PLOS ONE 8:e66753

Garcia SM (2011) Long-term trends in small pelagic and bottom fisheries in the Mediterranean: 1950-2008. Plan Bleu, Valbonne

*Gårdmark A, Casini M, Huss M, van Leeuwen A, Hjelm J, Persson L, de Roos AM (2015) Regime shifts in exploited marine food webs: detecting mechanisms underlying alternative stable states using size-structured community dynamics theory. Philos Trans R Soc Lond B Biol Sci 370: 20130262

*Garibaldi L, Caddy JF (1998) Biogeographic characterization of Mediterranean and Black Seas faunal provinces using GIS procedures. Ocean Coast Manag 39:211-227

Gower JC (1971) A general coefficient of similarity some of its properties. Biometrics 27:857-871

* Granger V, Fromentin JM, Bez N, Relini G and others (2015) Large spatio-temporal monitoring highlights shift in 
Mediterranean fish diversity hotspots. Prog Oceanogr 130:65-74

KGavel D, Poisot T, Abouy C, Velez L, Mouillot D (2013) Inferring food web structure from predator-prey body size relationships. Methods Ecol Evol 4:1083-1090

Guidetti P, Baiata P, Ballesteros E, Di Franco A and others (2014) Large-scale assessment of Mediterranean Marine Protected Areas effects on fish assemblages. PLOS ONE 9:e91841

Harmelin-Vivien ML, Kaim-Malka RA, Ledoyer M, JacobAbraham SS (1989) Food partitioning among scorpaenid fishes in Mediterranean seagrass beds. J Fish Biol 34: 715-734

Hattab T, Lasram FBR, Albouy C, Romdhane MS, Jarboui O, Cury P, Le Loc'h F (2013) An ecosystem model of an exploited southern Mediterranean shelf region (Gulf of Gabes, Tunisia) and a comparison with other Mediterranean ecosystem model properties. J Mar Syst 128: 159-174

Hubert L, Arabie P (1985) Comparing partitions. J Classif 2: 193-218

Hulot FD, Lacroix G, Loreau M (2014) Differential responses of size-based functional groups to bottom-up and topdown perturbations in pelagic food webs: a metaanalysis. Oikos 123:1291-1300

Hutchinson GE (1957) Concluding remarks. Cold Spring Harb Symp Quant Biol 22:415-427

Jennings S, Reñones O, Morales-Nin B, Polunin NVC, Moranta J, Coll J (1997) Spatial variation in the ${ }^{15} \mathrm{~N}$ and ${ }^{13} \mathrm{C}$ stable isotope composition of plants, invertebrates and fishes on Mediterranean reefs: implications for the study of trophic pathways. Mar Ecol Prog Ser 146: 109-116

Kalogirou S, Wennhage H, Pihl L (2012) Non-indigenous species in Mediterranean fish assemblages: contrasting feeding guilds of Posidonia oceanica meadows and sandy habitats. Estuar Coast Shelf Sci 96:209-218

Karachle PK, Stergiou KI (2010a) Gut length for several marine fish: relationships with body length and trophic implications. Mar Biodivers Rec 3:1-10

Karachle PK, Stergiou KI (2010b) Intestine morphometrics of fishes: a compilation and analysis of bibliographic data. Acta Ichthyol Piscat 40:45-54

Lamouroux N, Poff LN, Angermeier PL (2002) Intercontinental convergence of stream fish community traits along geomorphic and hydraulic gradients. Ecology 83: 1792-1807

Layman CA, Langerhans RB, Winemiller KO (2005) Body size, not other morphological traits, characterizes cascading effects in fish assemblage composition following commercial netting. Can J Fish Aquat Sci 62:2802-2810

* Le Bourg B, Daniela D, Claire S, Nowaczyk A and others (2015) Trophic niche overlap of sprat and commercial small pelagic teleosts in the Gulf of Lions (NW Mediterranean Sea). J Sea Res 103:138-146

Leibold MA, Chase JM, Shurin JB, Downing AL (1997) Species turnover and the regulation of trophic structure. Annu Rev Ecol Syst 28:467-494

Libralato S, Coll M, Tempesta M, Santojanni A and others (2010) Food-web traits of protected and exploited areas of the Adriatic Sea. Biol Conserv 143:2182-2194

Lloret J, Lleonart J, Solé I, Fromentin JM (2001) Fluctuations of landings and environmental conditions in the northwestern Mediterranean Sea. Fish Oceanogr 10:33-50

Lotze HK, Coll M, Dunne JA (2011) Historical changes in marine resources, food-web structure and ecosystem functioning in the Adriatic Sea, Mediterranean. Ecosystems 14:198-222

McClanahan TR, Ruiz Sebastián C, Cinner J, Maina J, Wilson S, Graham NAJ (2008) Managing fishing gear to encourage ecosystem-based management of coral reefs fisheries. Proc 11th Int Coral Reef Symp, Ft Lauderdale, FL 2:1012-1016

* Möllmann C, Folke C, Edwards M, Conversi A (2015) Marine regime shifts around the globe: theory, drivers and impacts. Philos Trans R Soc Lond B Biol Sci 370:20130260

* Motta PJ, Clifton KB, Hernandez P, Eggold BT (1995) Ecomorphological correlates in ten species of subtropical seagrass fishes: diet and microhabitat utilization. Environ Biol Fishes 44:37-60

Mouillot D, Albouy C, Guilhaumon F, Ben Rais Lasram F and others (2011) Protected and threatened components of fish biodiversity in the Mediterranean sea. Curr Biol 21: 1044-1050

Moutopoulos D, Libralato S, Solidoro C, Stergiou KI (2013) Toward an ecosystem approach to fisheries in the Mediterranean Sea: multi-gear/multi-species implications from an ecosystem model of the Greek Ionian Sea. J Mar Syst 113-114:13-28

MyOcean (2014) MyOcean products. www.myocean.eu (accessed 20 August 2014)

Nikolsky GV (1963) The ecology of fishes. Academic Press, London

Oddo P, Adani M, Pinardi N, Fratianni C, Tonani M, Pettenuzzo D (2009) A nested Atlantic-Mediterranean Sea general circulation model for operational forecasting. Ocean Sci 5:461-473

*Peck LS, Webb KE, Bailey DM (2004) Extreme sensitivity of biological function to temperature in Antarctic marine species. Funct Ecol 18:625-630

* Petchey OL, Gaston KJ (2006) Functional diversity: back to basics and looking forward. Ecol Lett 9:741-758

*Philippart CJM, Anadon R, Danovaro R, Dippner JW and others (2011) Impacts of climate change on European marine ecosystems: observations, expectations and indicators. J Exp Mar Biol Ecol 400:52-69

* Piet GJ (1998) Ecomorphology of a size-structured tropical freshwater fish community. Environ Biol Fishes 51:67-86

* Pinnegar JK, Trenkel VM, Tidd AN, Dawson WA, du Buit MH (2003) Does diet in Celtic Sea fishes reflect prey availability? J Fish Biol 63:197-212

Polis GA, Holt RD (1992) Intraguild predation: the dynamics of complex trophic interactions. Trends Ecol Evol 7: 151-154

R Development Core Team (2015) R: a language and environment for statistical computing. R Foundation for Statistical Computing, Vienna

Rao CR (1964) The use and interpretation of principal component analysis in applied research. Sankhya Ser A 26: 329-358

* Reecht Y, Rochet MJ, Trenkel VT, Jenning S, Pinnegar JK (2013) Use of morphological characteristics to define functional groups of predatory fishes in the Celtic Sea. J Fish Biol 83:355-377

Relini G, Relini M, Torchia G, De Angelis G (2002) Trophic relationships between fishes and an artificial reef. ICES J Mar Sci 59:S36-S42

* Rijnsdorp AD, Peck MA, Engelhard GH, Möllmann C, Pinnegar JK (2009) Resolving the effect of climate change on fish populations. ICES J Mar Sci 66:1570-1583 
Rochet MJ, Trenkel VM, Carpentier A, Coppin F and others (2010) Do changes in environmental pressures impact marine communities? An empirical assessment. J Appl Ecol 47:741-750

Rochet MJ, Collie JS, Trenkel VM (2013) How do fishing and environmental effects propagate among and within functional groups? Bull Mar Sci 89:285-315

Rombouts I, Beaugrand G, Fizzala X, Gaill F and others (2013) Food web indicators under the Marine Strategy Framework Directive: From complexity to simplicity? Ecol Indic 29:246-254

Rousseeuw PJ (1987) Silhouettes: a graphical aid to the interpretation and validation of cluster analysis. J Comput Appl Math 20:53-65

Sibbing FA, Nagelkerke LAJ (2001) Resource partitioning by Lake Tana barbs predicted from fish morphometrics and prey characteristics. Rev Fish Biol Fish 10:393-437

Sommer U, Gliwicz ZM, Lampert W, Duncan A (1986) The PEG-model of seasonal succession of planktonic events in fresh waters. Arch Hydrobiol 106:433-471

Southwood TRE (1977) Habitat, the templet for ecological strategies. J Anim Ecol 46:337-365

Stergiou KI, Karpouzi VS (2002) Feeding habits and trophic levels of Mediterranean fish. Rev Fish Biol Fish 11: $217-254$

Editorial responsibility: Stylianos Somarakis, Heraklion, Greece
Therneau TM, Atkinson B (2011) R port of rpart by Brian Ripley. Some routines from vegan - Jari Oksanen. Extensions and adaptations of rpart to mvpart by Glenn De'ath. mvpart: multivariate partitioning. $\mathrm{R}$ package version 1.4-0. http://CRAN.R-project.org/package=mvpart

Thompson RM, Brose U, Dunne JA, Hall RO Jr and others (2012) Food webs: reconciling the structure and function of biodiversity. Trends Ecol Evol 27:689-697

* Trenkel VM, Pinnegar JK, Dawson WA, du Buit MH, Tidd AN (2005) Spatial and temporal structure of predatorprey relationships in the Celtic Sea fish community. Mar Ecol Prog Ser 299:257-268

Vaquer-Sunyer R, Duarte CM (2008) Thresholds of hypoxia for marine biodiversity. Proc Natl Acad Sci USA 105: 15452-15457

Vézina AF, Platt T (1988) Food web dynamics in the ocean. 1. Best-estimates of flow networks using inverse methods. Mar Ecol Prog Ser 42:269-287

Villéger S, Mason NH, Mouillot D (2008) New multidimensional functional diversity indices for a multifaceted framework in functional ecology. Ecology 89:2290-2301

* Ward JHJ (1963) Hierarchical grouping to optimize an objective function. J Am Stat Assoc 58:236-244

*Webb PW (1984) Form and function in fish swimming. Sci Am 251:72-82

Submitted: January 14, 2016; Accepted: September 29, 2016 Proofs received from author(s): November 14, 2016 